\title{
PROPERTIES OF SINTERED CU/SiC COMPOSITES
}

\author{
Zbigniew BAŁAGA, Monika GWOŹDZIK \\ Czestochowa University of Technology, Institute of Materials Engineering, Czestochowa, Poland, EU, \\ balaga.zbigniew@wip.pcz.pl
}

https://doi.org/10.37904/metal.2019.914

\begin{abstract}
The paper presents the results of research on the preparation of composites based on copper matrix reinforced with silicon carbide $(\mathrm{SiC})$ contents of $0,5,10$ and $15 \mathrm{wt} \%$. Materials were compacted by one-sided pressing, followed by sintering at a temperature of $800{ }^{\circ} \mathrm{C}$ for one hour. One-sided pressing was used, with pre-set pressure of $60 \mathrm{kN}$ and the rate of $200 \mathrm{~N} / \mathrm{s}$. The examinations of the composites included macroscopic and microscopic examinations (LM, SEM), XRD measurements, determination of density, hardness measurements, and a compression test. Microscopic examinations were performed using light microscopy (LM, 2D and 3D images), and scanning electron microscopy (SEM). XRD measurements were aimed to evaluate phase composition. The composites were measured using a Seifert 3003T/T X-ray diffractometer with radiation generated by a tube with a cobalt anode $\left(\lambda_{C_{0}}=0.17902 \mathrm{~nm}\right)$. X-ray examinations were performed, with the measurements based on the symmetric Bragg-Brentano geometry. The computer software and the DHN PDS crystallographic database were used for phase identification. Hardness measurements were made using the Brinell method. The test results showed that the optimal content of silicon carbide in $\mathrm{Cu} / \mathrm{SiC}$ composites is $10 \%$.
\end{abstract}

Keywords: $\mathrm{Cu} / \mathrm{SiC}$ sinters, light microscopy, XRD, mechanical properties

\section{INTRODUCTION}

With continuous advances in technology, the need arises for developing new materials with improved properties compared to conventional solutions. With requirements of the automotive, aerospace, shipbuilding and energy industries, researchers have to face new challenges, with their efforts directed towards the development of composite materials, commonly known as composites [1-6]. Currently, many research centers focus not only on the examinations of very expensive composites using, for example, carbon nanotubes [7], graphene, etc., but also those that can be made from much cheaper components, e.g. basic metal powders $\left(\mathrm{Cu}, \mathrm{Fe}, \mathrm{Al}\right.$ and $\mathrm{SiC}$ ceramics, $\left.\mathrm{Al}_{2} \mathrm{O}_{3}, \mathrm{ZrO}_{2}\right)$ [8-17].

Metal-based composites can be produced both using conventional casting methods and powder metallurgy. Nowadays, powder metallurgy offers many technologies to obtain materials, from the simplest and cheapest solutions consisting in uniaxial pressing and sintering to the more advanced and complex HIP or SPS methods [18-20].

Composites based on copper obtained by means of powder metallurgy can offer an interesting alternative to its conventional alloys.. Due to the low hardness or abrasion resistance of pure copper, these properties can be attempted by modifying the proportion of the reinforcing phase, e.g. ceramic particles. This combination should allow the partial retention of typical metal properties, such as plasticity or thermal conductivity, and the increase in properties such as hardness or abrasion resistance.

\section{MATERIAL AND METHODS}

The first stage of the study was the preparation of an appropriate amount of copper powder and silicon carbide powders to obtain compacts of varying mass composition $(0,5,10$ and $15 \mathrm{wt} \% \mathrm{SiC}$ content). The size of the 
powders was presented in paper [21]. The blend of copper and SiC powder was compacted. One-sided pressing was used, at pre-set pressure of $60 \mathrm{kN}$ and the rate of $200 \mathrm{~N} \mathrm{~s}^{-1}$. Specimens were pressed using a ZwickRoell Z100 testing machine. The next stage consisted in sintering of the compacts at $800{ }^{\circ} \mathrm{C}$ for 1 hour. The design of one-sided moulding was presented in paper [21].

Thorough examinations of the composites comprised:

- microscopic examinations performed using light microscopy (LM, 2D and 3D images), and scanning electron microscopy (SEM).

- $\quad \mathrm{XRD}$ measurements aimed to evaluate phase composition; the composites were measured using a Seifert 3003T/T X-ray diffractometer with radiation generated by a tube with a cobalt anode $(\lambda \mathrm{Co}=$ $0.17902 \mathrm{~nm}$ ). X-ray examinations were performed, with the measurements based on the symmetric Bragg-Brentano geometry. The computer software and the DHN PDS crystallographic database were used for phase identification.

- $\quad$ the density of the composites was determined using a hydrostatic scales (at ambient temperature, with distilled water used as a reference liquid)

- hardness measurements were made using the Brinell method with a ball with a diameter of $2.5 \mathrm{~mm}$ and a load of $153.2 \mathrm{~N}$ in accordance with current standards

- $\quad$ static compression test (The static compression test was carried out on a ZwickRoell Z100 testing machine with a compression rate of $100 \mathrm{~N} \cdot \mathrm{s}^{-1}$ )

\section{RESULTS AND DISCUSSION}

The results of density tests showed that the density of the sinters was decreasing with the increasing content of silicon carbide (Table 1). This can be attributed to e.g. uneven distribution of porosity in the sinter. Sintering process led to a decrease in the pore volume in the material. Large pores disappeared while a higher number of finer pores were formed, which was the most noticeable in the case of the copper powder. Detailed results of structural tests for these sinters were presented in the paper [21]. Furthermore, studies have shown that a smaller amount of porosity was observed at the side of the upper stamp, mostly in the copper matrix. However, the opposite effect was observed near silicon carbide. The pores were changing into gaps at the interface between the copper matrix and SiC particles. This was most evident in the case of the addition of $15 \%$ of silicon carbide [21]. Furthermore, density and quantity of individual powders has also an effect on density of the composites.

Brinell hardness was measured at the area of the side of the upper and lower stamps used in the moulding process. The results showed an increase in hardness of the sinters, with an increase in the SiC content to 10 $w t \%$ (Table 1). The addition of silicon carbide to $15 \mathrm{wt} \%$ caused a slight decrease in hardness. Furthermore, slightly higher values of hardness were observed from the upper stamp side. The X-ray diffractograms obtained for the compacts and sinters confirmed the presence of inhomogeneities in the structure, as evidenced by the varying intensity of the peaks coming from these phases (Figure 1).

Table 1 Density and hardness of sinters

\begin{tabular}{|c|c|c|c|}
\hline Mass composition & $\begin{array}{c}\text { Density } \\
\left(\mathrm{g} / \mathrm{cm}^{3}\right)\end{array}$ & $\begin{array}{c}\text { HB } \\
\text { (Sinter from upper } \\
\text { stamp) }\end{array}$ & $\begin{array}{c}\text { HB } \\
\text { (Sinter from bottom } \\
\text { stamp) }\end{array}$ \\
\hline $100 \% \mathrm{Cu}$ & 6.966 & 21.1 & 18.4 \\
\hline $95 \mathrm{wt} \% \mathrm{Cu} / 5 \mathrm{wt} \% \mathrm{SiC}$ & 6.764 & 26.9 & 22.4 \\
\hline $90 \mathrm{wt} \% \mathrm{Cu} / 10 \mathrm{wt} \% \mathrm{SiC}$ & 6.289 & 39.9 & 38.1 \\
\hline $85 \mathrm{wt} \% \mathrm{Cu} / 15 \mathrm{wt} \% \mathrm{SiC}$ & 5.782 & 38.2 & 36.4 \\
\hline
\end{tabular}




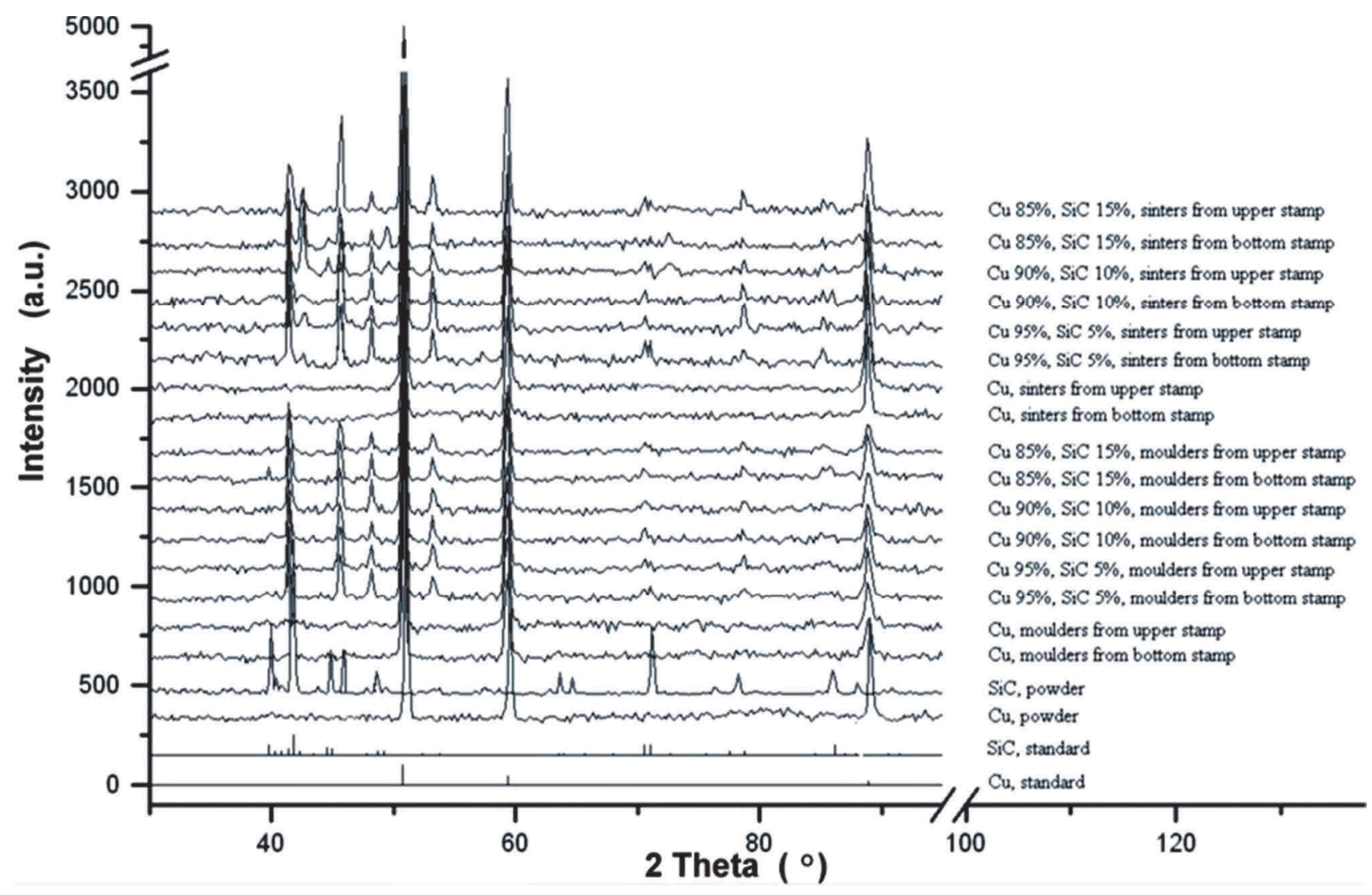

Figure $1 \mathrm{X}$-ray diffractions of researched materials

Due to the high plasticity of the pure copper specimens, a static compression test was carried out by loading the specimens with a pressure of $560 \mathrm{MPa}$, followed by macroscopic and microscopic observation of their external surfaces (Figure 2 and 3 ). The results of macroscopic (LM) and microscopic examinations (SEM) after the compression test showed that the addition of $10 \% \mathrm{SiC}$ is an optimal choice, which was confirmed by previous results published in the study [21]. No microcracks were observed after the compression test, both in the case of pure copper and copper with an addition of 5 and $10 \mathrm{wt} \%$ silicon carbide. Furthermore, the addition of $\mathrm{SiC}$ in the amount of $15 \mathrm{wt} \%$ led to the appearance of a significant number of microcracks, which were visible on the outer layer of the specimen. In some places, the cracks were so large that they caused local chipping of up to $400 \mu \mathrm{m}$. However, no microcracks were observed in the core material. In the paper [15], researchers documented similar findings. These authors examined the effect of the content and size of SiC used for the frictions materials based on the $\mathrm{Cu}-\mathrm{Fe}$ matrix obtained using powder metallurgy. The strengthening effect of nano-silicon carbide was greater than that of micro silicon carbide. The friction coefficients of friction materials increased with the increasing nano-SiC content. However, the wear rate decreased with the increasing nano-SiC content and then increased when the content of nano-SiC particle exceeded $10 \mathrm{wt} \%$. The specimen containing $10 \%$ of nano-SiC had the best tribological properties in different testing conditions [15].

Microscopic 2D and 3D observations of upper surfaces (Figure 4) were confirmed by macroscopic (LM) and microscopic observations using scanning electron microscope (SEM). No microcracks were found inside the specimens (Figure 4), but cracks were observed at the lateral surface in the specimen containing $85 \mathrm{wt} \% \mathrm{Cu}$ and $15 \mathrm{wt} \% \mathrm{SiC}$ (Figure 3). 

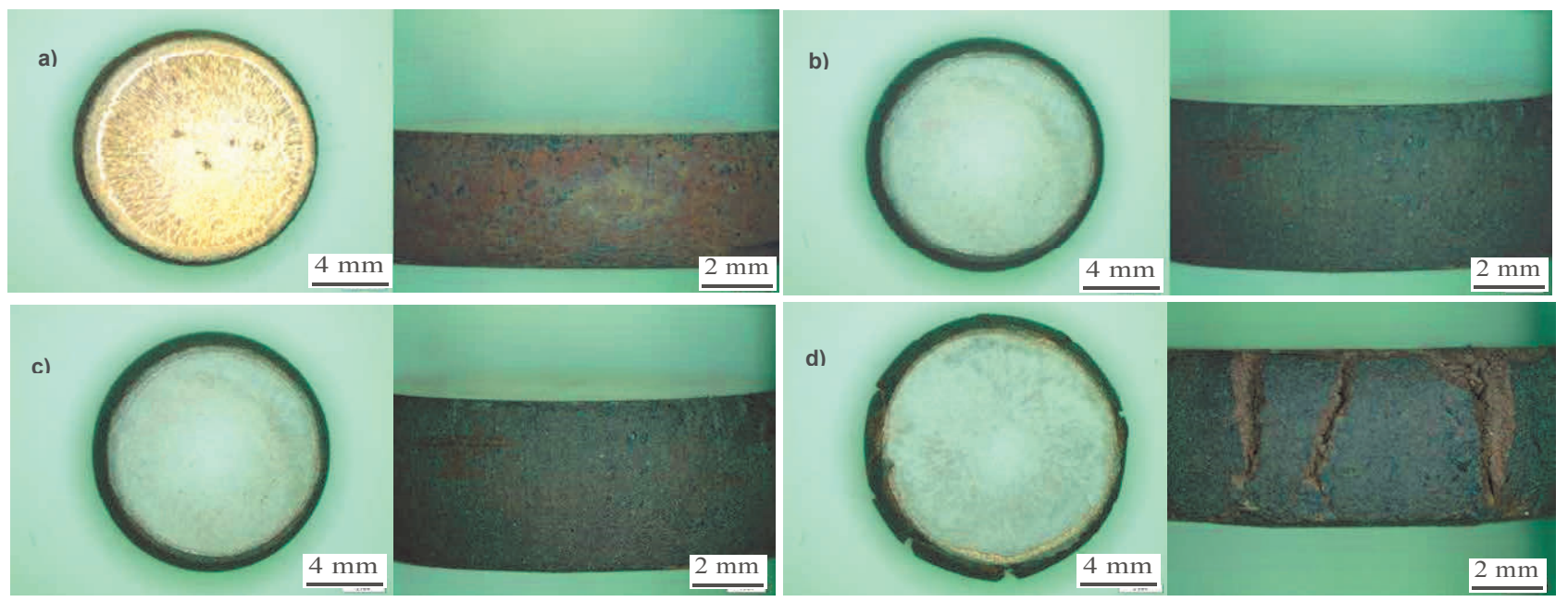

Figure 2 Macro images after compression test view from above and side view: a) $100 \% \mathrm{Cu}$,

b) $95 \mathrm{wt} \% \mathrm{Cu} / 5 \mathrm{wt} \% \mathrm{SiC}, \mathrm{c}) 90 \mathrm{wt} \% \mathrm{Cu} / 10 \mathrm{wt} \% \mathrm{SiC}$, d) $85 \mathrm{wt} \% \mathrm{Cu} / 15 \mathrm{wt} \% \mathrm{SiC}$
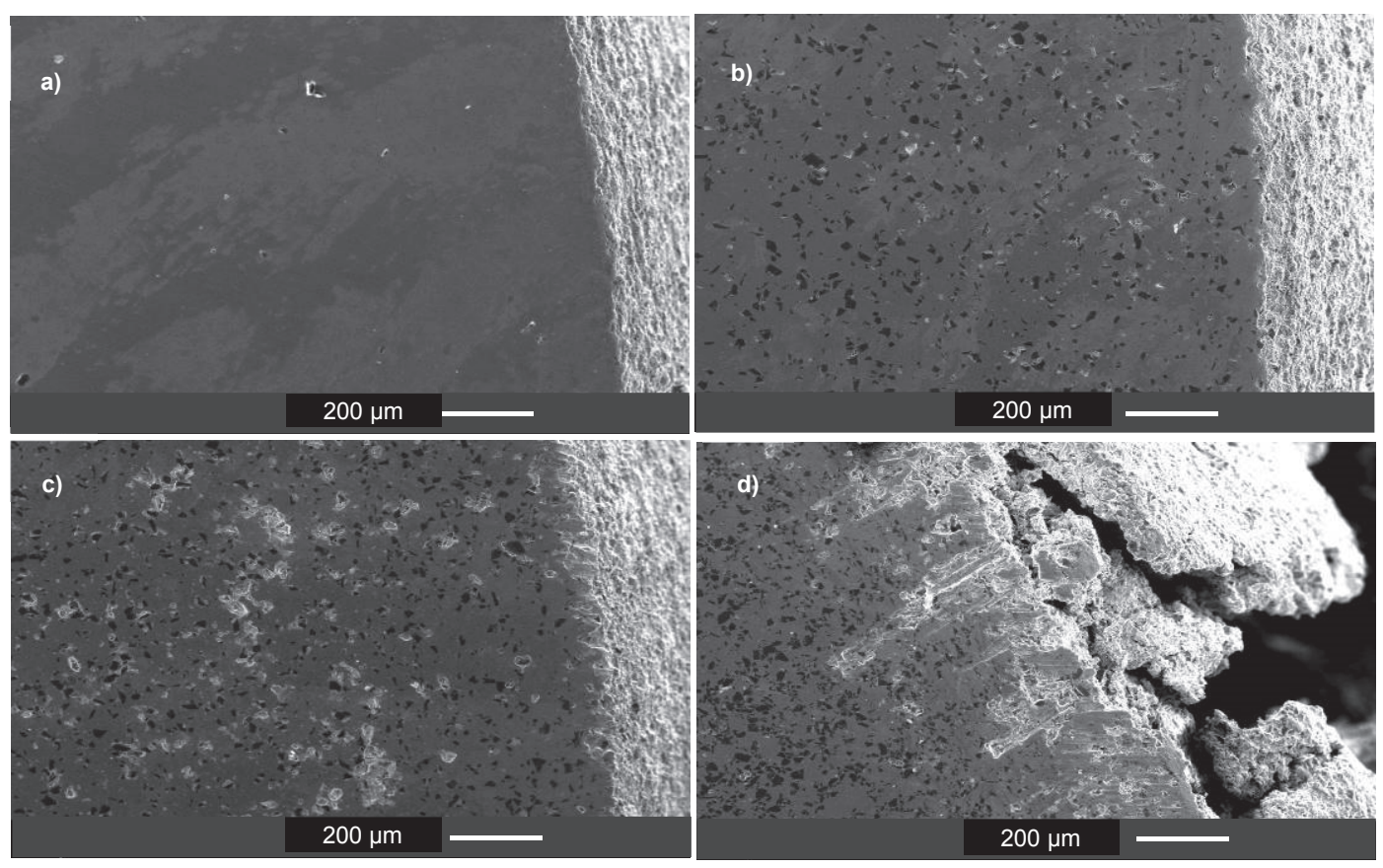

Figure 3 SEM images after compression test, top view: a) $100 \% \mathrm{Cu}$,

b) $95 \mathrm{wt} \% \mathrm{Cu} / 5 \mathrm{wt} \% \mathrm{SiC}$, c) $90 \mathrm{wt} \% \mathrm{Cu} / 10 \mathrm{wt} \% \mathrm{SiC}$, d) $85 \mathrm{wt} \% \mathrm{Cu} / 15 \mathrm{wt} \% \mathrm{SiC}$

\section{CONCLUSION}

Based on the study carried out, it was found that:

- with the increase of silicon carbide reinforcement phase, the density of sinters obtained decreased,

- an increase in hardness was found along with an increase in the SiC content to $10 \mathrm{wt} \%$, a higher addition of this phase causes a reduction in hardness, which is caused by a rapid increase in porosity around $\mathrm{SiC}$ particles,

- the compression test carried out confirmed that the optimum SiC content is $10 \mathrm{wt} \%$, higher contents cause cracking and crushing of the sintered product under the effect of compressive stresses. 


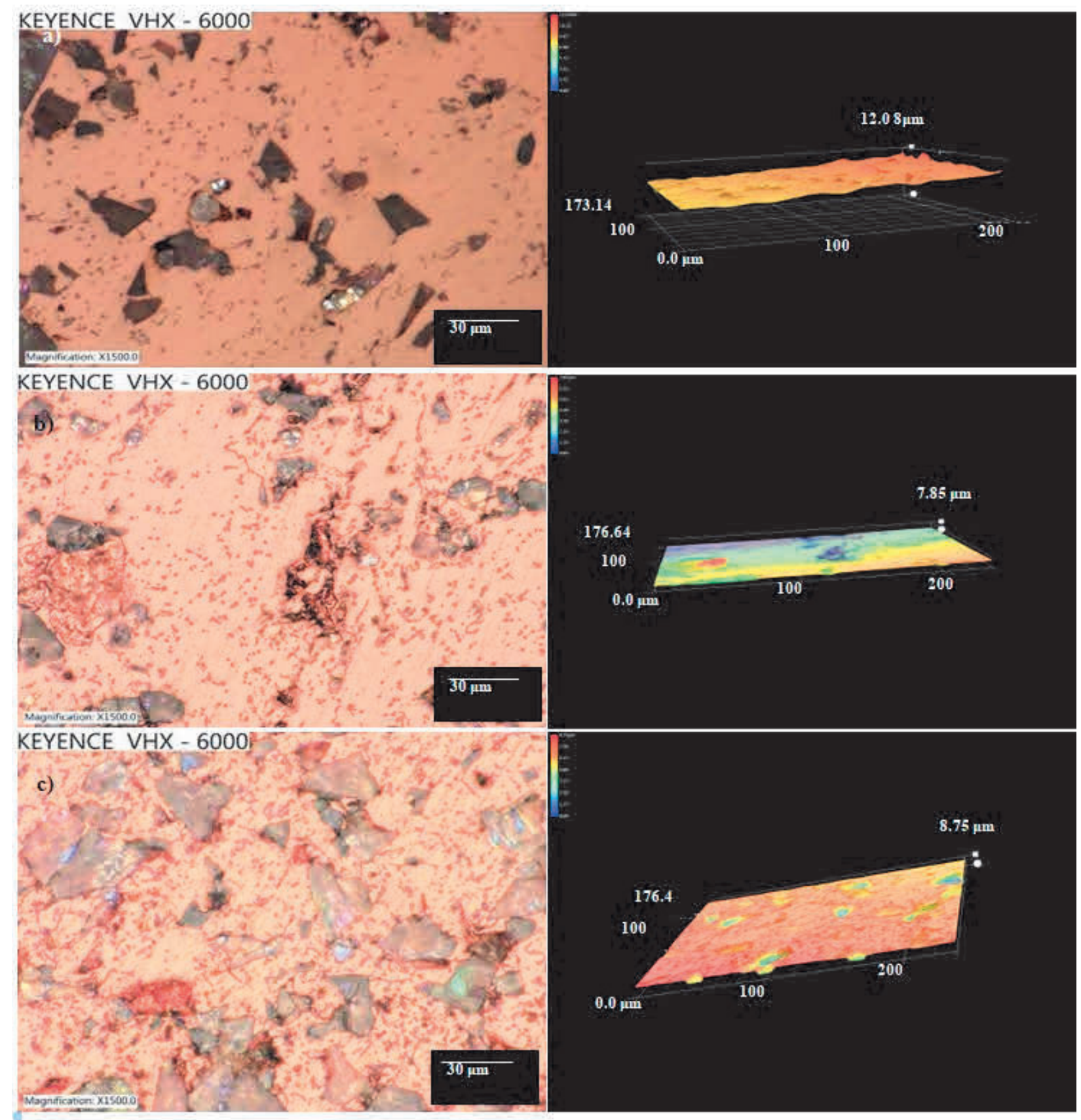

Figure 4 Example of microscopic images after compression test, top view $2 \mathrm{~d}$ and $3 \mathrm{~d}$ : a) $95 \mathrm{wt} \% \mathrm{Cu} / 5 \mathrm{wt} \% \mathrm{SiC}$, b) $90 \mathrm{wt} \% \mathrm{Cu} / 10 \mathrm{wt} \% \mathrm{SiC}$, c) $85 \mathrm{wt} \% \mathrm{Cu} / 15 \mathrm{wt} \% \mathrm{SiC}$

\section{REFERENCES}

[1] RABIEE, M., MIRZADEH, H. and ATAIE, A. Processing of $\mathrm{Cu}-\mathrm{Fe}$ and $\mathrm{Cu}-\mathrm{Fe}-\mathrm{SiC}$ nanocomposites by mechanical alloying. Advanced Powder Technology. 2017. vol. 28, pp. 1882-1887.

[2] HU, M., ZHANG, YL., TANG, LL., SHAN, L. GAO, J. and Ding, PL. Surface modifying of SiC particles and performance analysis of SiCp/Cu composites. Applied Surface Science. 2015. vol. 332, pp. 720-725.

[3] JAHEDI, M., PAYDAR, M.H. and KNEZEVIC, M. Enhanced microstructural homogeneity in metal-matrix composites developed under high-pressure-double-torsion. Materials Characterization. 2015. vol. 104, pp. 92100. 
[4] LIA, J., LIU, B., FANG, Q.H., HUANG, Z.W. and LIU Y.W. Atomic-scale strengthening mechanism of dislocationobstacle interaction in silicon carbide particle-reinforced copper matrix nanocomposites. Ceramics International. 2017. vol. 43, pp. 3839-3846.

[5] GHANBARI, D., ASGARANI, M.K., AMINI, K. and GHARAVI, F. Influence of heat treatment on mechanical properties and microstructure of the Al2024/SiC composite produced by multi-pass friction stir processing. Measurement. 2017. vol. 104, pp. 151-158.

[6] BAŁAGA, Z., PRZYBYCIN, A., WAWRZYNIAK, J. and GNATOWSKI, A. Examinations of the effect of montmorillonite on selected properties and structure of polybutylene terephthalate. Composites Theory and Practice. 2017. no. 3, pp. 175-179.

[7] ZYGOŃ, P., GWOŹDZIK, M. PESZKE, J. and NITKIEWICZ, Z. Comparison of properties of polymer composite materials reinforced with carbon nanotubes. Archives of Metallurgy and Materials. 2015. no. 3, pp. 193-198.

[8] PROSVIRYAKOV A.S. SiC content effect on the properties of Cu-SiC composites produced by mechanical alloying. Journal of Alloys and Compounds. 2015. vol. 632. pp. 707-710.

[9] SHABANI, M., PAYDAR, M.H., ZAMIRI, R.and GOODARZI, M., MOSHKSAR, M.M., Microstructural and sliding wear behavior of SiC-particle reinforced copper matrix composites fabricated by sintering and sinter-forging processes. Journal of Materials Research and Technology. 2016. vol. 5, no. 1, pp. 5-12.

[10] BETKE U., SHARMA, K.S.K., Rodak, A., RANNABAUER, S., LIEB, A., SCHEFFLER, F. and SCHEFFLER, M. Manufacturing of an electrically conducting cellular $\mathrm{Cu}-\mathrm{SiC}$ material by metal salt infiltration and chemical reduction. Materials Letters. 2016. vol. 185, pp. 201-203.

[11] EL AAL, M.I.A. Effect of high-pressure torsion processing on the microstructure evolution and mechanical properties of consolidated micro size Cu and Cu-SiC powders. Advanced Powder Technology. 2017. vol. 28, pp. 2135-2150

[12] JARZĄBEK, D.M., MIELCZAREK, M., WOJCIECHOWSKI, T., DZIEKOŃSKI, C. and CHMIELEWSKI, M. The effect of metal coatings on the interfacial bonding strength of ceramics to copper in sintered Cu-SiC composites. Ceramics International. 2017. vol. 43, pp. 5283-5291.

[13] LIU, M., BAI, S.X., LI, S., ZHAO, X. and XIONG, D.G. Microstructure and Thermal Properties of SiCp/Cu Composites with Mo Coating on SiC Particles. Journal of Wuhan University of Technology-Mater. Sci. 2017. vol. 32, pp. 1013-1018.

[14] ZHOU, Y.G. and HU, M. Mechanical behaviors of nanocrystalline Cu/SiC composites: An atomistic investigation. Computational Materials Science. 2017. vol. 129, pp. 129-136.

[15] CUI, G., REN, J. and LU, Z.X., The Microstructure and Wear Characteristics of Cu-Fe Matrix. Friction Material with Addition of SiC. Tribology Letters [online]. 2017 65:108, [vieved 2018-06-15]. Available from: DOI: 10.1007/s11249-017-0890-0.

[16] JEONG, Y.K., KIM, Y.S. and OH, S.T. Fabrication of Cu-based SiC composites by spark plasma sintering of Cunitrade coated SiC powders. Archives of Metallurgy and Materials. 2017. Vol. 62, no.2B, pp.1407-1410.

[17] GWOŹDZIK, M., BAŁAGA, Z., WRÓBEL, D. and NITKIEWICZ, Z. Evaluation of wear degree of rotational instruments with diamond coat. Composites Theory and Practice. 2017. no. 4, pp. 216-220.

[18] CHMIELEWSKI, M., PIETRZAK, K., TEODORCZYK, M., NOSEWICZ, S., JARZĄBEK, D., ZYBAŁA, R., BAZARNIK, P., LEWANDOWSKA, M. and STROJNY-NĘDZA. A., Effect of metallic coating on the properties of copper-silicon carbide composites. Applied Surface Science. 2017. vol. 421, pp. 159-169.

[19] MEHER, A. and CHAIRA, D. Effect of Graphite and SiC Addition into Cu and SiC Particle Size Effect on Fabrication of Cu-Graphite-SiC MMC by Powder Metallurgy. Trans Indian Inst Met. 2017. vol. 70, no. 8, pp. 20472057.

[20] CHMIELEWSKI, M., PIETRZAK, K., STROJNY-NĘDZA, A., JARZĄBEK, D. and NOSEWICZ, S. Investigations of interface properties in copper-silicon carbide composites. Archives of Metallurgy and Materials. 2017. vol. 62, no. 2B, pp. 1315-1318.

[21] GWOŹDZIK, M. and BAŁAGA, Z. Microstructure of sintered Cu/SiC Composites. Composites Theory and Practice. 2018. no. 3, pp. 95-102. 